\title{
Investigating Trauma in Narrating World War I: A Psychoanalytical Reading of Pat Barker's Regeneration
}

\author{
Bakhtiar Sadjadi (Corresponding author) \\ University of Kurdistan, Sanandaj, Iran \\ E-mail: b.sadjadi@uok.ac.ir \\ Farnaz Esmkhani \\ IA University, Tehran Central Branch, Iran
}

Doi:10.7575/aiac.alls.v.7n.6p.189

URL: http://dx.doi.org/10.7575/aiac.alls.v.7n.6p.189
Received: 11/09/2016

Accepted: 16/11/2016

\begin{abstract}
The present paper seeks to critically read Pat Barker's Regeneration in terms of Cathy Caruth's psychoanalytic study of trauma. This analysis attempts to trace the concepts of latency, post-traumatic stress disorders, traumatic memory, and trauma in Barker's novel in order to explore how trauma and history are interrelated in the narrative of past history and, particularly, in the history of World War I. The present paper also demonstrates how Barker's novel Regeneration acts as the narrative of trauma that vocalizes the silenced history of shell-shocked soldiers of World War I to represent British society, the history that has been concealed due to social and individual factors. The study thus investigates the dissociative disorders which are experienced by traumatized survivors of World War I as the aftermath of traumatic experiences of wartime. In addition, it argues how time moves for the traumatized victim and how the notion of latency in terms of Caruth's theory is traceable in Barker's novel. In Regeneration, the traumatized survivors are haunted with traumatic memory of past history; furthermore, past history constantly disrupts their present and the victims are in continuous shift from present time to past time. Time thus loses its linearity in the narrative of traumatized survivors.
\end{abstract}

Keywords: Latency, post-traumatic stress disorders, traumatic memory, trauma

\section{Introduction}

The initiation of post-traumatic stress disorder (PTSD) to both areas psychiatry and psychoanalysis in 1980 is conceived as a major turning point in contemporary trauma studies. The outset of trauma theories brought the concept of trauma fiction through which the literary critics pursue the interrelation of trauma and literature. Literary critiques question how trauma fiction narrativizes the event that overwhelms the survivor. Cathy Caruth in her introduction to Trauma: Explorations in Memory inaugurated a comprehensive description of trauma besides recounting the present conceptual challenges on trauma theory. Caruth declares that the starting point of traumatic pathology, coined as PTSD, cannot be determined by, or located in a given traumatic event; trauma advances the assumption that traumatic events do not simply occur in a specific time.

Trauma consists of an event or experiences that overwhelm the victim and withstands language or representation, a conception that questions the narrative nature of traumatic event. At the rise of trauma theory the novelists, including Pat Barker, seek to explore how the traumatic past is remembered rather than what is remembered. Barker's desire to voice specific moments of traumatic history has brought about novels such as Regeneration. Barker perceived the outcoming impact of trauma to be representable only through narratives that include repetition and indirection, since in traumatic experience time has lost its linearity and chronology.

\section{Critical Approach and Concepts}

Cathy Caruth in her introduction to Trauma: Explorations in Memory considers the phenomenon of trauma to become all-inclusive; however, she argues that it has done so precisely in that it brings us to the limits of understanding. For Caruth, trauma is an interdisciplinary concept to be explored in relation with history, psychoanalysis, psychology, literature, sociology, and pedagogy. Regarding literature as a discipline that can be effective in understanding trauma, in Unclaimed Experience, Caruth assumed literature, like psychoanalysis, to be "interested in the complex relation between knowing and not knowing. And it is at the specific point at which knowing and not knowing intersect that the language of literature and psychoanalytic theory of traumatic experience precisely meet."(8). Indeed, dislocatabilty of traumatic event in a specific time zone, in the past, brings about the hunting existence of traumatic memory to the survived victim. For Caruth, "the text of psychoanalysis, of literature, and of literary theory-both speak about and through the profound story of traumatic experience."(9). Unspeakable is a discourse in trauma theory, for which, Caruth has coined the name "unclaimed experience". The origin of discourse of unspeakable is the terrible account of psychical and sexual abuses that has been silenced all through the history. It is a hunting history that historians and literary critics 
attempt at revealing in order to heal the wound of traumatized victims through this revelation that brings reconciliation. Caruth argues about the victim's ability to recover repressed memories after the period of latency, which is inherent in the traumatic experience. In Unclaimed Experience, Caruth demonstrates that, to entirely integrate the full impression of trauma, concurrent with its occurrence, resists its very inherent nature:

Traumatic experience... suggests a certain paradox: that the most direct seeing of a violent event may occur as an absolute inability to know it; that immediacy, paradoxically, may take the form of belatedness. The repetitions of the traumatic event - which remain unavailable to consciousness but intrude repeatedly on sight - thus suggest a larger relation to the event that extends beyond what can simply be seen or what can be known, and is inextricably tied up with the belatedness and incomprehensibility that remain at the heart of this repetitive seeing." (91-92; emphasis added).

In line with Caruth's explorations, it can be assumed that, part of traumatic memory will be denied upon its effects. Still, recurrence of trauma persists against this denial. Integrated into survivor's mind and thought, the bitter memories appear in the form of symptoms like nightmares, hallucinations, depression, and anxiety. These converted reactions concretizes the body's function in remembering the traumatic experience, correspondingly, the traumatized survivor can regain his/her mental health through psychotherapy sessions that accredit the recovery of repressed memories via free associations. In Trauma: Explorations in Memory, Caruth demonstrates that, for survivors, the therapy sessions may "imply the giving-up of an important reality, or the dilution of a special truth into the reassuring terms of therapy" (ix). In "Recapturing the Past", Caruth emphasizes that while the traumatized "are called upon to see and relive the insistent reality of the past, they recover a past that encounters consciousness only through the very denial of active recollection."(152), she suggests that an overwhelming experience that has been obstructed by a later repression or amnesia does not return in the flashback, rather there is an event that is itself constituted, in part, by its lack of integration to consciousness. Correspondingly, there exists a direct interrelation between the "literal integration of an event" with the manner that "it escapes full consciousness as it occurs." (153)

In the area of trauma theory, destructiveness and survival are directly codependent. Due to this, in her critical essay "Traumatic Departures: Survival and History in Freud," Caruth challenges to determine as she mentions the "enigma of survival", "it is only in recognizing traumatic experience as a paradoxical relation between destructiveness and survival that we can also recognize the legacy of incomprehensibility at the heart of catastrophic experience." (29) In order to expand her explorations she focuses on Freud's two seminal works, mainly, Beyond the Pleasure Principle and Moses and Monotheism. Written during World War I and World War II, these books, are illuminative in proving, according to Caruth, a direct relation between Freud's theory of trauma and historical violence, a directness presumably that is reflected in the theory of trauma he produced. For Caruth, studies of Freud in these books verify the "incomprehensibility of human survival" with regards to trauma theory. Through his explorations on the damaged psyche of the survivors of World Wars, Freud observed that the repetitive nightmares and flashbacks are neither avoidable nor controllable, seeing that they do not have any comprehensible meaning in the psyche. Freud undertakes traumatic neurosis to be the peculiar and perplexing experience of survival." Being unconscious to the event at the moment of its occurrence, the flashbacks and nightmares are the only witness to a survival that the traumatized is unable to comprehend, yet, this does not mean that unconsciousness and survival are directly interrelated, since, as Caruth attributes it to be originating from the very paradoxical structure of indirectness in psychic trauma. Freud argues that the experience of survival is not intelligible for consciousness, because, if it is a conscious experience, it does not appear in the form of symptoms, dreams, and flash backs, in his book, Beyond the Pleasure Principle, Freud acclaims that:

People think the fact that the traumatic experience is constantly forcing itself upon the patient even in his sleep is a proof of the strength of that experience: the patient is, as one might say, fixated to his trauma.... I am not aware, however, that patients suffering from traumatic neurosis are much occupied in their waking lives with memories of their accident. Perhaps they are more concerned with not thinking of it. (13)

The gap of time between the moment of occurrence and preparedness of the mind to understand it, engenders, as Freud calls it, the "missing of the experience". The continual presence of traumatic experience being dramatized as dreams, flashbacks, and somatic symptoms, originally, comes from the survivor's everlasting challenge to control and comprehend the indirect experience to which he/ she was not fully awake at the moment of its occurrence, "for consciousness then, the act of survival, as the experience of trauma, is the repeated confrontation with the necessity and impossibility of grasping the threat to one's own life." (Traumatic Departure 33)

Since psyche fails to consciously experience the life threat, it cannot avoid the repetition of the destructive occurrence. Consequently, this disturbing repetition of devastating event rules and ruins the life of each traumatized individual all through his/ her life. As Caruth claims, the history of traumatized victim is in fact "the determined repetition of the event of destruction" (33). On the basis of this view, Caruth points to traumatic disorder as indeed an apparent struggle to die: The "postulation of a drive to death... would seem only to realize the reality of the destructive force that the violence of history imposes on the human psyche, the formation of history as the endless repetition of previous violence." (33)

There always exists a delayed experience of the traumatic event; Caruth here borrows the term "latency" from Freud for this situation. In her introduction to Trauma: Explorations in Memory, she demonstrates latency as the period during which the effects of the experience are not apparent. Latency is not the aftermath of forgetting the traumatic event for some period; indeed, traumatic experience is built upon an inherent latency. The time-breach between the instant of the 
happening of traumatic event and its belated experience by the victim is, in point of fact, preserving the literality of trauma. In Unclaimed Experience, trauma is delineated by Caruth as the breach in the mind's experience of time, self, and the world...is experienced too soon, too unexpectedly, to be fully known and is therefore not available to consciousness until it imposes itself again, repeatedly, in the nightmares and repetitive actions of the survivor. Consequently, for a narrative to be recognized as a narrative of trauma the representative voice of the event should be foregrounded to the extent that it is not fully perceived as it occurs. Thus, the gaps at the center of the structure of traumatic events require indirect modes of signification to represent their unrestrained nature, which is forcing trauma narrative to struggle for referentiality that obstinately remains beyond their grip. Therefore, Caruth asserts that, the traumatic experience provides a unique opportunity, since:

It is here, in the equally widespread and bewildering encounter with trauma - both in its occurrence and in the attempt to understand it - that we can begin to recognize the possibility of a history that is no longer straightforwardly referential (that is, no longer based on simple models of experience and reference). Through the notion of trauma ... we can understand that a rethinking of reference is aimed not at eliminating history but at resituating it in our understanding, that is, at precisely permitting history to arise where immediate understanding may not (UE 11).

If trauma is to be better understood, there should be an urge for its history. Caruth applies this latency of trauma to the narrative of history in order to explain the interrelation of trauma and history; on the other hand, she questions the authenticity of history. The event is so intense that it shatters the linearity of time for the victim's full comprehension of the event in the moment of its occurrence. Trauma is not recorded as it occurs but is rather re-experienced belatedly. The problem that arises, for the literary text in struggling to bear witness to traumatic experience, is the same as the paradox inherent in the mind's fragmented recognition of an event that persistently remains outside its reach. To textually narrow a trauma that, through its inherent nature, escapes from the grasp of consciousness shall automatically urge the act of going beyond the conventional means of representation. Trauma conveys a crisis of time and challenges traditional modes of representation. While the referential paradox of trauma is transferred into the field of history, trauma theory becomes an strengthening motive of the deconstructive view that narrative cannot correspond to the entirety of history. History, as Caruth asserts, is "symptomatic of trauma." Accordingly, this history of trauma is considered by its two-faced impacts: its urge for witness and its avoidances of full comprehension. (Explorations 5)

In accordance with, "inherent latency of the event", Caruth furthers her studies to consider this latency to be central to the experience of historical trauma. She considers latency as a history that can be grasped only in the very inaccessibility of its occurrence, the process of narration of traumatic event helps the survivor to understand the event that he or she refused to realize psychically at the moment of its occurrence. For Caruth, "latency" through which the event returns to recapture the victim is, exactly and ironically the pathway toward history, an indirect entree troubled with the uncertainty of memory, such choice questions the authority of historical accounts because it creates, as Caruth assumes, a "crisis of truth" that is the outcome of the tension between the event's instant presence and delayed effects (Explorations 6).

\section{Literature Review}

Pat Barker has done a great endeavor in portraying the suffering of British society in the First World War. History is one of the key concepts discussed in Barker's works. Sharon Monteith in her introduction to Critical Perspective to Pat Barker (2005) indicates that in Barker's fiction, history is a broad and encircling pressure on the lives of her characters. Although narrating traumatic experience, especially the traumatic experience of war veterans, will help to gain a pure image of the history, Monteith acknowledges that the characters in Barker's novels have reached significant insight about their social and psychological circumstances and yet are usually drawn back into the frameworks that control and oppress them. The soldiers in Regeneration (1991) act in accordance with Monteith's viewpoint in that most of the traumatized veterans in the novel seek for returning to battlefields after their recovery. Barker's trauma narratives are not merely limited to individuals. While depicting the individual trauma of working class women and war veterans as individuals; Barker indicates the social trauma too. Monteith goes on to claim that "historical events, such as war, can traumatically change both individual and social identities" ( $p$ vii). Choosing the historical setting for her novels provides Barker with a fundamental basis for perceiving and understanding present time traumas, with an attempt to prevent future traumas. Subsequently, Barker looks for finding a connection between past, present and future through narrating the past history by giving voice to present memory of the traumatized.

How the narration of trauma can lead to the reproduction of history? This is a highly significant question to pose while reading Barker's novels. Anne Whitehead is a major contributor in the field of trauma studies and the interrelation of trauma narratives with history. Since Regeneration (1991) and Another World (1998) are explicitly the composition of the First World War period through the retelling of the traumatic experiences of traumatized soldiers, Whitehead argues that these novels are the apparent proofs to indicate that trauma narratives can reshape, rewrite, and recapture the past history. In her critical essay Open to Suggestion: Hypnosis and History in the Regeneration Trilogy (2005), Whitehead argues that, Barker is negotiating, throughout the novel Regeneration, issues of historicity. For Whitehead, Regeneration (1991), "regenerates the past or returns us to the event. The function of trauma narrative in the reproduction of past history is that it alters that event and new perspectives are taken on it; in short, it is transformed." Barker's novel radically questions the very possibility of the regeneration of the past.

Beside the concept of history in Barker's novels, the notion of time is also focused by the contemporary critics in this area. David Waterman, in his critical analysis of Barker's works, turns toward the notion of time in her novels in 
relation to trauma. In his well-known book, Pat Barker and Mediation of Social Reality (2009), Waterman indicates that despite the overriding theme of regeneration, time in Barker's novels is not necessarily linear and cyclical, since the notion of recovery depends on "constantly flowing of stream" of time." (5) Through investigating the flow of time in Another World (1998) and Regeneration (1991), Waterman argues that since in these novels there is endless shift of time through the retelling of past memory from old Geordie's perspective in Another World (1998), and mentally ill war veterans in Regeneration (1991), "time seems to be stuck in continuous present." (Ibid) Anne Whitehead, too, declares in her book, Trauma Fiction (2004), that Barker's literary genre of the ghost story is drawn and revised so that the specters, that is the particular ghost of each soldier, that haunt the soldiers represent a form of psychological possession.

Diana Wallace, whose major interest is the representation of British women and who is specialized in the field of historical novel has studied the linearity of time in Barker's novels, particularly, Regeneration Trilogy (1996) and Another World (1998). In her critical paper "Dialogues with the Dead: History and the Sense of Ending," Wallace regards Barker as the representative of British society of World War the First. She asserts that Barker is the "voice of the past" who connects the past with present British society. For Wallace, Regeneration Trilogy (1996) is a watershed between a lost past and the present which is not familiar and intelligible but fractured and haunted by the trauma of the past.

\section{A Trauma Reading of Pat Barker's Regeneration}

Regeneration is particularly renowned as a major contribution to the literature of war. The remarkable success of this novel is due to its careful blend of history and fiction, its bold experimentation with well-known subject of World War I, along with, its ambitious examination of social and political processes. The originality of this novel is because of its delayed description of battlefield until the very last part of the novel. Up to the final part, the reader has indirect access to the war through the fragmented battle memories and testimonies of shell-shocked veterans cured in Britain while the war is still continuing. Consequently, Regeneration studies the home front and the soldiers' internal conflicts between their agonizing memories and the demands of British society at war.

\subsection{The Concept of Time in Trauma and the Haunting Past}

For the traumatized veterans of Regeneration, time and space have become profoundly unstable concepts. The traumatized soldiers in this novel live in a different time-based and spatial world, a world in which differences between now and then, here and there, have distorted. The earthly boundaries that explain the zone of combat have been eliminated and original space of war has expanded and spread everywhere. The English Coast and the Scottish countryside resemble the muddy frontline under heavy rain; the empty corridors of a hospital are "like a trench without the sky" (Regeneration, 17), and the landing of prison is similar to the landscape of nobody's land, "apparently devoid of life," but "actually containing millions of men." (Regeneration, 170) The veterans' experience of time is durational rather than chronological, and they continue to experience the fears of the war through internal shifts back in time and space. The war is displaced from history, recurring in the present against the will and control of the subject:

He woke to find Orme standing immediately inside the door. He wasn't surprised; he assumed Orme had come to rouse him for his watch. What did surprise him, a little, was that he assumed to be in bed... This clearly didn't worry Orme, who continued to stand quietly by the door, but Sassoon began to think it ought to worry him. Perhaps if he turned his head it would be all right. He stared at the window's pale square, and when he looked back Orme had gone. (Regeneration, p113)

In Regeneration, the impossible history of World War I is relived and re-experienced as a hunting presence. The ghost figure which structures blatantly, powerfully, symbolizes the disjointedness of time and space after the traumatic experience of battlefield. In Regeneration, Barker reconstructs history as a trauma that needs to be studied and examined through the ghost of the dead soldier, Orme, actually, embodies the horrors and anxieties of Sassoon for war. Sassoon feels guilty for not fighting in the battlefields, as well, he persistently encounters with his grief for the dead men in Great War. Sassoon is possessed with the image of the shattered bodies in battlefield. Time does not move chronologically for him, while being in Craiglockhart, he is consistently possessed with the agonizing memories of war. To be traumatized for Sassoon is actually to be obsessed by his past history, which is the history of battlefields. The latter re-emergence of the experience is against the conscious will and control of him.

\subsection{The Talking Cure and the Paradox of Recovery}

Doctor Rivers attempts at releasing his shell-shocked patients from the ghosts of the war and help them to escape from the trauma time. Rivers offers them a Freudian therapy based on the articulation and narration of the past, a "talking cure" that will consent them to deal with and to challenge their trauma. Trauma victims continue to live with an event that could not and did not advance through its completion, has no ending, achieved no closure, and hence, as far as its survivors are concerned, continued into the present and is current in every aspect. The narration of the event gives it a beginning and closure, and thus allows it to achieve an ending. Since it takes place before a witness, the narration of a past in therapeutic session becomes a testimony, empowered by the very existence of the listener to trauma. Rivers is the ardent listener who helps his patients to bear witness, to testify to the repulsions that they have experienced, and thus to transform their non-verbal memory of the body into narrative memory.

Rivers confesses that the process of testifying is tortuous and challenging, since the witness has to overcome different hindrances through his period of recovery. The veterans are unwilling to tell their traumatic experience, as well, the truth of traumatic experience resides not in the violence of its experience but in its mere incomprehensibility. 
Consequently, witnessing is not impossible for the victims, but it has the possibility of betraying the truthfulness of the past history:

In leading his patients to understand that breakdown was nothing to be ashamed of, that horror and fear were inevitable responses to the trauma of war and were better acknowledged than suppressed, that feelings of tenderness for other men were natural and right, that tears were an acceptable and helpful part of grieving, he was setting himself against the whole tenor of their upbringing...In advising young patients to abandon the attempt at repression and to let themselves feel the pity and terror their war experience inevitably evoked, he was excavating the ground he stood on. (Regeneration, 41)

Here Rivers conceives that through persuading the survivors to narrate the story of their past history, he weakens the basis of masculinity and their education as a man, which threaten their role as a male gender in society. Rivers' patients are in constant struggle with internal dilemma between their urge for recovery from the pain of past history and their need to preserve their sense of belonging and identity as members of British society and culture, these soldiers' anxieties of duty and manly heroism are discordant with their nature of self-protection. Regeneration represents how war intensifies the traditional notions of masculinity and femininity, as well as, pressurizing the characters to adapt themselves to these social and gender codes, rather than putting an end to them. Indeed, the war is both the most masculine of the duties and concurrently the action which imposes the most extreme pressure on manliness:

Obviously he and Yealland were both in the business of controlling people. Each of them fitted young men back into the role of warrior, a role they had-however unconsciously-rejected. He'd found himself wondering once or twice recently what possible meaning the restoration of mental health could have in relation to his work. Normally a cure implies that the patient will no longer engages in behavior that is clearly self-destructive. But in present circumstance, recovery meant the resumption of activities that were not merely self-destructive but positively suicidal. But then in war nobody is a free agent. He and Yealland were both locked in, every bit as much as their patients were. (Regeneration, p180)

After witnessing Yealland's method of treatment through electro-shock therapy, Rivers saw a nightmare in which he tries to shove a horse's bit into the mouth of a patient who resists him. Thinking about his dream, Rivers realizes that the patient who resisted him was Sassoon, consequently, he concludes that his nightmare originates from his sense of control on the patients. Bit is an instrument of control, which symbolizes the sense control that Rivers applies on his patients. As well, he questions the logic of the therapy sessions, through which, he tries to persuade the survivors about their sanity and health, so that he can comfort them about returning to battlefields which is the origin of their mental break down. Rivers, likewise, compares his methods of therapy with Yealland's, to conclude that they both act in the same manner through inflicting pain on the patients to release them from their anxieties, along with, preparing them to return to front lines.

The dilemma that the witness of war has to encounter is highly intense in nature, for his testament inescapably turns against himself and his own securities in this explicit circumstance of a therapy in wartime. Indeed, the talking cure does not, simply, intend to free the soldiers from their emotional and somatic sufferings, but seeks to make them standard for combat again. Testimony is thus both vital and possibly fatal for the witness, for, in telling his history of past, he runs the risk of retrieval and his subsequent instant returnto the front. Rivers is very much aware of the schizophrenic state in which his patients find themselves, and of his own uncertain role, as an army psychologist, in sending these young men to the very circumstances that triggered their mental breakdown. As he himself puts it, "normally a cure implies that the patient will no longer engage in behavior that is clearly self-destructive. But in present circumstances, recovery meant the resumption of activities that were not merely self-destructive but positively suicidal" (p180). When doctor Yealland practices an electro shock on a mute soldier to force him to speak and on the other hand tells him "You must speak but I shall not listen to anything you say" (Regeneration,p175), Rivers conceives that what Yeallands does is actually a more vividly brutal version of what he himself does. Both Rivers and Yealland challenge to silence the unconscious protest of the traumatized soldiers, preformed through their bodily symptoms, in order to return them to battlefields. This is the greatest irony in Regeneration. Indeed, the soldiers in Craiglockhart are condemned to fight, to suffer, and to die for the sake of protecting the country and their manliness. Regeneration, thus, registers a crisis of testimony, which turns out to be both cure and venom for the witness, obliged to testify against himself and his own interests.

\subsection{Traumatic Body: Eye and Mouth, Symbols of Traumatized Body}

The distressing aftermath of traumatic experience is multifaceted in some occasions via which the survivor challenges both mental disorders and psychosomatic disabilities. While traumatic experience appears in the form of hallucinations, flashbacks, and nightmares to mentally trouble the victim, on the other hand, it troubles the victim in the form of bodily dysfunctions or, psychosomatic disorders, such as, stammering, mutism, vomiting, trouble headaches, and visual problems. These psychosomatic disorders of the shell-shocked soldiers are highly presented in Regeneration, particularly, as conversation disorders. Through Regeneration Barker seeks to probe the psychosomatic patterns that oblige the individuals to speak through their body, the novel is compelled with images of mouth and eye both of which are associated with vocality and visibility. Silence of the patients is, indeed, their protest against the war. Whereas Sassoon declares his protest through writing an anti-war declaration, other patients, namely, Prior, registers his protest through his silence in his conversations with Rivers in therapy sessions. The mutism, stammering, nightmares, and hallucinations are the traumatized soldiers' reactions to war: 
Thrope arrived. 'D-d-d-do w-w-w-w-wwe kn-kn-know wwhwhat's t-t-t-t-taking s-s-so 1-1-long?' he asked after a while.

Sassoon shook his head. Pugh shook his head too, though whether in answer to the question it was difficult to tell.

$[\ldots]$

Pugh was quick and distressing. Since the orderly had gone off to have dinner, Rivers himself went into the waiting room to summon Sassoon. Thrope was sitting there alone. 'Have you seen Sassoon?'

'He's...' Thrope went into one of his paroxysms. 'G-g-g-g-g-gone.'

'G-g-?' Deep breath. ' ehere has he gone?'

Thrope economized with a shrug. (Regeneration, p158)

Thrope is suffering from a speech disorder, which Barker typographically embodies in this moment of novel through Thrope's conversations with Rivers. The image of the shuttering or speechless mouth represents the need to testify and its impossibility most obviously. A stammer is both sign of a potent longing to speak, but also to preserve the special force and truth of the event from the misrepresentations intrinsic to narration, and to keep one's experience for oneself. It is the concrete symptom of traumatic memory which encompasses the repetition, the excess and the unconceivable chaos inherent to trauma. In addition, it displays both the desire and the inability to verbalize. Caught between the impossibility to speak, and the impossibility not to speak, the victims can only stammer. The images of eye and mouth in Regeneration figure the trauma of the witness and his effort to verbally translate in a coherent form what his body is trying to say.

Prior [...] found himself staring into an eye. Delicately, like somebody selecting a particularly morsel from a plate, he puts his thumb and forefinger down through the duckboards. His fingers touched the smooth surface and slid before they manage to get a hold. He got it out, transferred it to the palm of his hand, and held it out towards Logan. He could see his hand was shaking, but the shaking didn't seem to have anything to do with him. "What am I supposed to do with this gob-stopper?" (Regeneration, p82)

Back from the trenches, Prior is completely unable to speak, for his jaw is paralyzed: "a numbness had spread all over the lower half of his face" (Regeneration, p103). The disembodied eye, which looks like a gob-stopper, a slang word for a round piece of candy, has thus factually stopped Prior's gob, which informally means mouth, as well as, rendering him speechless. Incapable of integrating, to swallow what he has just seen, Prior is condemned to re-enact this traumatic event. He is haunted and tortured by what he has seen, and specifically so at night. He is later hunted in his dreams by an eyeball. Indeed, the only time that Prior speaks about his shattered friend, Tower, is through one of his conversations with Rivers in therapy session, in which he painfully declares that "He had very blue eyes, you know, Towers, We used to call him the Hun." (Regeneration, 84)

The eye, consequently, serves as a powerful symbol of trauma; the image of the past, stored in the eyes of the witness, insistently, returns in the form of an eye to haunt the survivor. Indeed, Prior has undergone terrible situations, and is preoccupied, but also, identified by what he has encountered and experienced in front. The eye is the symbol of what Prior has to free himself from; on the other hand, it is the only reminder of where he belongs, and what he has experienced in reality. Psychologically, Prior is in constant internal conflict between forgetting the bitter facts and holding them powerfully.

\subsection{Narrative of Trauma and Reconstructing the Past History}

The painful reliving of the past history represents the intrusion of interrupted and anachronistic crash of temporalities to the traumatized soldiers. Initiating in a traumatic moment of shock without affect, the dislocated history represents a past that has not been experienced at the time at which it occurred. The event is displaced from historical process and the effects with which it is accompanied streams back irrepressibly into the present moment, causing a painful and intense belated experiencing of trauma. Dream, as recurrent motif all through Regeneration is, indeed, the passage for the revival of the past history. In Regeneration, memory functions as a narrative form, narrative of unvoiced history. Barker challenges to voice the unvoiced history of trauma to the present generation of British society, via regenerating the traumatic history of World War I. The past painfully and compulsively inhabits the present of the survivors. Thus, the past is available, but the patient is reluctant to face the horrific memory of traumatic history. Here Rivers performs as the motivator to encourage the patients to speak the past history of war.

What passing-bells for these who die...so fast?

-Only the monstrous anger of the guns.

'Well, there's nothing wrong with the second line.'

'In herds"?'

'Better.'

They worked on the poem for half an hour. The wind had been rising all evening, and the thin curtain

billowed in draught. At one point Sassoon looked up and said, 'What's that noise?' (Regeneration, 111)

Through these lines Barker exhibits the urge of the soldier-poets to possess the past, to capture it in a precise description, while their desire is undermined by the power of the past to return as a form of possession or haunting. 
Sound of a shell directly triggers the unconscious desire of the traumatized soldier to confront the hidden aspects of his own past history. Both Owen and Sassoon undergo a moment of reconstructing the past history. Via composing poem of war, they express their hidden urge to remember in an indirect manner. The two poets' commitment with remembering the sight of warfare and searching for the "precise word" for the sound of shell passing overhead derives from desire to regenerate the past history. They try to reconstruct the unknown past by delicate attentiveness and conscious recall. Also, through their recurrent nightmares and hallucination, the two poets agree upon the fact that the past history can, furthermore, return instinctively of its own accord.

In this scene of the novel, the hunting past reappears in the form of an autumnal wind. The presence of a violent storm outside surrounds Craiglockhart and itself becomes a power of war. The patients within the hospital are forcibly returned to their wartime experiences, those who are already haunted by the past now take on the appearance of being infatuated:

The wind went on rising all evening. By the time Sassoon left Owen's room, it was wailing round the building, moaning down chimneys, snapping branches off trees with a crack like rifle fire. All over the decayed hydro, badly fitting windows rattled and thumped, and Sassoon, passing several of his "fellow breakdowns" in the corridor, thought they looked even more "mental" than usual. (Regeneration, 112)

The irony with traumatized soldiers is, indeed, in their vigorous sensitivity toward past, along with their strong conscious reluctance to face their past history. Narrative of their traumatic past provides the readers with an access to the silenced history of World War I, firstly through narrative of historical figures like, Sassoon and Owen, who have been fictionalized in Barker's Regeneration. Secondly, the traumatized survivors articulate their past history to Rivers in therapy session, which enables the communication of silenced history:

Rivers watched the play of emotions on Prior's face as he fitted the recovered memory into his past. He was unprepared for what happened next...He put his head in his hands, at first, it seemed, in bewilderment, but then after a few moments he began to cry. Rivers waited a while, then walked around the desk and offered his handkerchief. Instead of taking it, Prior seized Rivers by the arms, and began butting him in the chest, hard enough to hurt. This was not an attack, Rivers realized, though it felt like one. It was the closest Prior could come to asking for physical contact. (Regeneration, 83)

The history that is represented at this stage of the novel is the potent desire to possess the past. This section of the novel is remarkable for dramatizing the moment of transition of the patient's history from being haunted past into a narrative in which Rivers uncover a version of patient's, namely, Prior's, past history to recover him from despair. Having brought Prior out of his hypnotic state, Rivers waits, contentedly, for Prior to assimilate the experience into his consciousness. Prior's reaction at this moment echoes the state of person instantly after state of release. Prior has freed himself from the heavy memory of his traumatic history. He is engaged in process of connection between his past and present; also, he drives pleasure from the sense of conquering the past through interpretation. However, his pleasant fleeing of release is immediately denied through his reaction to the memory that has been recovered.

At this point in the novel, Barker represents the seductive power of the narrative. Narrative is based on even advancement and chronology, the state of retrieval for Prior contents his longing for continuous narrative with unexplained gaps or contradictions. However, his response interrupts the convictions that seem to be obvious in the text. The narrative of the recovered memory does not appear to him to be as adequate as the story with which he himself filled in the progressive interruptions in his memory. In Prior's version of his past he himself was guilty for the death of his men, by losing his way in the bewildering geography of the trenches, he opened fire on his own men. The recovered version of his past appears to Prior insufficient in comparison with his own narrative. Barker's narrative raises the question of the historical status of the traumatic event, there raises the problem in relation to unknown history, because regarding the notion of narrative, in this case, the most persuasive narrative account can become a substitute for the event itself.

Through the Regeneration, Barker is debating on the issue of historicity. The act of writing a narrative is always indirectly a method of repetition. In Barker's case this account is obviously applicable, since Regeneration promises that it will regenerate the past or return us to the event. This is precisely the aim of narrative, apparently, it is able to recall the events that it describes, but as its nature, it always and necessarily dissatisfies the reader. This paradoxical nature of narrative is vividly represented in Prior's recovered memory. This is the only section of the novel at which the past is possessed as form of knowledge, while in most of the other sections of the novel it is the past that troubles and dominates the patients. Actually, Barker challenges to show that traumatic event problematizes concept of history and how traumatized survivors are related to past.

\section{Conclusion}

World has gone through considerably dramatic times in which people of different societies were object to intense violence. History is compelled with accounts of the vicious acts, crimes, and genocide, namely, Holocaust, World War I, World War II, and the most recent one 9/11 attack. Trauma is the most explicit aftermath of these violent histories. Trauma as one of the major concerns in the realm of psychoanalysis is, correspondingly, highly, presented in the world of literature. The catastrophic events of Holocaust, slavery, and the great wars are the subjects of outstanding literary works. The First and Second World Wars and their aftermath are among the major concerns of authors such as the British author Pat Barker. Her novels, including Regeneration, are the true representatives of World War I and the 
trauma of this violent event that continues to disturb the survivors till the present time. Barker's Regeneration is considered to be the representative voice of traumatized victims of World War I to the present society of Britain who are unfamiliar to the true nature of history of this war. The traumatized soldiers of Barker's novel represent the repressed aspect of the British wartime society. Barker assumes that these traumatized veterans are marginalized in contemporary British society; consequently, narrating the trauma of this marginalized group is a reaction to the repression that has been imposed on this people by postwar English society.

\section{References}

Barker, Pat. Regeneration. London: Penguin Book, 1992.

---. Regeneration Trilogy. London: Plume, 1996.

Boccardi, Mariadele. The Contemporary British Historical Novel: Representation, Nation, Empire. London: Palgrave McMillan, 2009, pp. 1-28.

Brannigan, John. Pat Barker. Manchester: Manchester University Press, 2005, pp. 146-93.

Brown, Laura. "Not Outside the Range: One Feminist Perspective on Psychic Trauma" Trauma: Exploration in Memory. Ed. Caruth, Cathy. Maryland: John Hopkins University Press, 1995, pp. 100-12.

Caruth, Cathy. Empirical Truths and Critical Fiction: Locke, Wordsworth, Kant, Freud. Baltimore: John Hopkins University Press, 1991.

---. "History as False Witness: Trauma, Politics, and War" Witness: Memory, Representation, and Media in Question. Ed. Ekman, Ulrik, and Tygstrup, Frederik. Copenhagen: Museum Tusculanum Press, 2008, pp. 150-71.

---. "Recapturing the Past: Introduction" Trauma: Explorations in Memory. Ed. Baltimore: John Hopkins University Press, 1995, pp. 151-58.

---. "Trauma and Experience: Introduction" Trauma : Explorations in Memory. Ed. Baltimore: John Hopkins University Press, 1995, pp. vii-13.

---. "Unclaimed Experience: Trauma and the Possibility of History" Yale French Studies 79 (1997): 181-192. Literature and the Ethical Question. http://jstor.org/sici?sici=00440078\%281991\%290\%3A79\%3C181\%3AUETATP\%3E2.0.CO\%3B2-L. 17 July 2013.

---. Unclaimed Experience: Trauma, Narrative, and History. Baltimore: John Hopkins University Press, 1996.

Figley. R, Charles. "Introduction” Trauma and Its Wake. Ed. Bristol: Brunner/ Mazel, 1985, pp. xvii-5.

Freud, Sigmund. Beyond the Pleasure Principle. Ed. Dufrence, Todd. Toronto: Broadview Editions, 2010.

Frust. R, Lilian. Idioms of Distress: Psychosomatic Disorders in Medical and Imaginative Literature. New York: State University of New York Press, 2003, pp. 169-97.

Holmgren Troy, Maria. "Matrix, Metramorphosis, and the readymade in Union Street, Liza's England, and Another World" Re-Reading Pat Barker. Ed. Wheeler, Pat. Newcastle: Cambridge Scholars Publishing, 2011, pp. 13-28.

---. "The Novelist as an Agent of Collective Remembrance: Pat Barker and the First World War" Collective Traumas: Memories of War and Conflict in $20^{\text {th }}$-Century Europe. Ed. Brussels: P.I.E PETER LANG, 2007, PP. 47-76.

Knutsen, P, Karen. Reciprocal Haunting: Pat Barker's Regeneration Trilogy. Karlstad: Karlstad University Studies, 2008.

Luckhurst, Roger. The Trauma Question. Abingdon: Routledge, 2008.

Monteith, Sharon. "Foreward" Re-Reading Pat Barker. Ed. Wheeler, Pat. Newcastle: Cambridge Scholars Publishing, 2011, pp. xiii-6.

Nixon, Rob. "An Interview with Pat Barker" Contemporary Literature 45.1 (2004), pp. vi-21.

Prescott, Lynda. "Pat Barker's Vanishing Boundaries" British Fiction of 1990s. Ed. Bently, Nick. Abingdon: Routledge, 2005, pp. 167-79.

Roots. P, Maria. "Reconstructing the Impact of Trauma on Responsibility" Personality and Psychopathology: Feminist Reappraisals. Ed. Ballou, Mary, Laura S. Brown. New York: Fuilford Press, 1992, pp. 241-45.

Schwab, Gabriele. Haunting Legacies: Violent Histories and Transgenerational Trauma. New York: Columbia University Press, 2010.

Steveker, Lena. "Reading Trauma in Pat Barker's Regeneration Trilogy" Ethics and Trauma in Contemporary British Fiction . Ed. Ganteau, Jean-Michel. New York: Rodopi, 2011, pp. 21-37.

Van. Der. Hart, Onno, and Van. Der. Kolk, Bessel. "The Intrusive Past: The Flexibility of Memory and the Engraving of Trauma" Trauma: Explorations in Memory. Ed. Caruth, Cathy. Baltimore: John Hopkins University Press, 1995, pp. 158-83.

Wallace, Diana. "Dialogue with Daed" The Woman's Historical Novel: British Women Writers, 1900-2000. Ed. Houndmills: Palgrave Macmillan, 2005, pp. 221-26.

Waterman F, David. Pat Barker and Mediation of Social Reality. New York: Cambridge Press, 2009, pp. 1-113.

Wheeler, Pat. "Introduction” Re-Reading Pat Barker. Ed. Newcastle: Cambridge Scholars Publishing, 2011, pp. xiii-6. Whitehead, Anne. Memory. New York: Routledge, 2009.

---. "Open to Suggestion: Hypnosis and History in the Regeneration Trilogy" Critical Perspectives on Pat Barker. Ed. Monteith, Sharon. South Carolina: South Carolina University Press, 2005, pp. vii-xi.

---. Trauma Fiction. Edinburg: Edinburg University Press, 2004, pp. 12-30. 